\title{
Casting Alloys: The Materials and "The Clinical Effects"
}

\author{
H.F. MORRIS ${ }^{1^{*}}$ \\ M. MANZ ${ }^{2}$ \\ W. STOFFER ${ }^{3}$ \\ D. WEIR ${ }^{4}$ \\ ${ }^{1}$ Clinical Research Center \\ for Restorative Materials \\ Veterans Affairs Medical Center \\ Ann Arbor, Michigan \\ ${ }^{2}$ Department of Dental Public Health \\ University of Michigan \\ ${ }^{3}$ Veterans Affairs Medical Center \\ Pittsburgh, Pennsylvania \\ ${ }^{4}$ Veterans Affairs Medical Center \\ San Francisco, California \\ "Present address, 45500 Green Valley Drive, \\ Plymouth, MI 48105
}

Adv Dent Res 6:28-31, September, 1992

This manuscript is published as part of the proceedings of the NIH Technology Assessment Conference on Effects and Sideeffects of Dental Restorative Materials, August 26-28, 1991, National Institutes of Health, Bethesda, Maryland, and did not undergo the customary journal peer-review process.
T $t$ is estimated that $96 \%$ of adults in the United States between the ages of 18 and 65 have one or more carious or filled teeth, with an average of almost 10 decayed or filled teeth for each adult (Miller et al., 1987). The best treatment for carious teeth, to prevent loss and restore masticatory function, often involves the use of cast dental restorations. This paper will discuss the chemical compositions of noble and base metal dental alloys and, based on 72-month data from a 10-year clinical study (Morris et al., 1986), will summarize the clinical behavior of alloys with "representative formulations". "Noble" refers to metals with marked resistance to oxidation and chemical reaction. Silver is not considered noble in the context of dental casting alloys. "Precious" refers to an economic value. The American Dental Association has stated that "semi-precious" has no meaning in dentistry because no definition has been agreed on (ADA, 1984). "Base metal" refers to metal elements that are chemically reactive to their environment (Phillips, 1991).

\section{TYPES OF DENTAL ALLOYS}

Dental alloys can be categorized as noble alloys (gold- and palladium-based) or base metal alloys (nickel- and cobaltbased). Major ( $>10$ at $\%$ ) and minor ( $<10$ at $\%)$ components of these different alloy types are shown in Tables 1-4.

\section{Noble Alloys}

\section{Noble/Gold-based Alloys}

Noble/gold-based alloys (Table 1) have the longest history of use in dentistry and are "the standard" with which other alloys are usually compared. They are used for fabrication of inlays, crowns, fixed partial dentures, and metal ceramic restorations (PFM). Gold adds high corrosion resistance, good castability, good ductility, and the distinctive yellow gold color. Silver reduces density, slowly whitens the alloy color when added in increasing amounts, and counteracts the redness of copper. In PFM alloys, silver may discolor porcelain veneers. Copper strengthens gold-based alloys $\left(\mathrm{AuCu}_{3}\right)$. Both palladium and platinum increase casting temperature, strength, and corrosion resistance of the alloy (Tuccillo and Nielson, 1971). Palladium lowers cost and improves rigidity and sag resistance of PFM alloys (Moffa, 1983). Zinc (traces) increases castability (Raub and Ott, 1983) and forms intermetallic (gold) compounds to harden the alloy (Labarage and Treheux, 1979). Iron improves mechanical properties and, in PFM alloys, increases sag resistance (Kojima, 1980) and bond strength with porcelain (Espevik and Øilo, 1979). Tin acts as a bonding element in PFM alloys and a hardening agent in palladium-gold alloys (German, 1979). Iridium acts as a grain refiner in gold-based PFM alloys (Raub and Ott, 1983). Indium serves as a bonding agent in PFM alloys (Espevik and Øilo, 1979). 
TABLE 1

NOBLE/GOLD-BASED ALLOYS: "GENERAL" CHEMICAL COMPOSITIONS

(A) Crowns and fixed partial dentures

(1) Major: gold, silver, copper

(2) Minor: palladium, platinum, zinc, indium, iridium, rhenium, germanium

(B) Metal ceramic (PFM)

(1) Major: gold, platinum, palladium

(2) Minor: rhodium, silver, indium, tin, iron, iridium, rhenium, copper

TABLE 2

NOBLE/PALLADIUM-BASED ALLOYS: "GENERAL" CHEMICAL COMPOSITIONS

(a) Crowns and fixed partial dentures

(1) Major: palladium, silver, copper, gold

(2) Minor: zinc, indium, iridium

(B) Metal ceramic (PFM)

(1) Major: palladium, silver, gold, copper, cobalt

(2) Minor: gold, platinum, indium,tin, gallium, ruthenium, rhenium

TABLE 3

BASE METAL/COBALT-BASED ALLOYS: "GENERAL" CHEMICAL COMPOSITIONS

(A) Metal ceramic (PFM)

(1) Major: cobalt, chromium, tungsten, molybdenum

(2) Minor: copper, silicon, gallium, aluminum, nickel, tantalum, ruthenium

(B) Removalbe partial dentures

(1) Major: cobalt, chromium, nickel

(2) Minor: molybdenum, tantalum, manganese, gallium, silicon, carbon, tungsten

Germanium increases the castability of gold-copper alloys (Townsend and Hamilton, 1983).

Noble/Palladium-based Alloys

Noble/palladium-based alloys (Table 2) with silver have been available since 1974 (Tuccillo, 1977). In the early 1980's, there was an increase in palladium-based formulations with reduced amounts of silver. They are used primarily for the fabrication of PFM restorations. However, a variety of type IV, extra-hard alloys exists that can be used to cast inlays, crowns, fixed partial dentures, and removable partial dentures (RPD). Palladium reduces the cost of the alloy while increasing strength, rigidity, and sag resistance (Moffa, 1983). The coefficient of thermal expansion is increased with the addition of silver (Kollmannsperger and Helfmeier, 1983). Indium and/ or tin can be added to improve bonding with the porcelain veneer. Gallium contributes to a homogeneous microstructure. Ruthenium is used primarily as a grain refiner. Palladiumbased alloys absorb small amounts of carbon that increase brittleness of the alloy (Eichner, 1983). Gas porosities (CO gas) may occur after the alloy is cooled. The palladium-silver alloys are somewhat more difficult to cast (McLean, 1983).

\section{Base Metal Alloys}

Base metal alloys (Tables 3 and 4) were first introduced to dentistry for the fabrication of RPD's in the early 1930's. Subsequently, they have largely replaced the noble-based alloys for RPD's. The most successful RPD alloys are cobaltchromium-based (Table 3) and nickel-chromium-based (Table 4). There has also been an increase in the use of similar "base metal" alloys for less costly crowns, fixed partial dentures, and PFM restorations due to the dramatic increase in price of gold bullion and gold-containing dental casting alloys in the 1970's.

\section{Base MetallCobalt-based Alloys}

Base metal/cobalt-based alloys (Table 3 ) are used primarily in the fabrication of RPD's. Several manufacturers (e.g., J.F. Jelenko, Dentsply) market cobalt-based alloys for PFM restorations. Cobalt provides strength, hardness, and corrosion resistance. Chromium provides hardness and resilience and increases corrosion resistance when present in at least $16 \mathrm{wt} \%$. Nickel increases ductility (Asgar and Peyton, 1961) while lowering melting temperature and hardness (Asgar and Allan, 1968). The carbon content of these alloys is critical. It is only 
TABLE 4

BASE METAL/NICKEL-BASED ALLOYS: "GENERAL" CHEMICAL COMPOSITIONS

(A) Crowns and fixed partial dentures

(1) Major: nickel, chromium, iron

(2) Minor: molybdenum, silicon, manganese, boron, copper

(B) Metal ceramic (PFM)

(1) Major: nickel, chromium

(2) Minor: molybdenum, iron, silicon, manganese, beryllium, boron, aluminum, yttrium, tin

(C) Removable partial dentures

(1) Major: nickel, chromium

(2) Minor: molybdenum, iron, silicon, manganese, beryllium, boron, aluminum, carbon, cobalt, gallium, tin

slightly soluble in cobalt-chromium solid solution and is present mainly as dispersed carbides of chromium, cobalt, or molybdenum, increasing the strength and hardness of the alloy (Tesk and Waterstrat, 1985). Manganese is a de-oxidizer. Tungsten helps reduce formation of chromium-depleted zones.

\section{Base MetallNickel-based Alloys}

Base metal/nickel-based alloys (Table4) are used primarily for RPD's and PFM restorations. Nickel yields a softer alloy and lowers the melting temperature. Aluminum $\left(\mathrm{Ni}_{3} \mathrm{Al}\right)$ increases strength and hardness. Carbon may be added to increase strength but increases brittleness as well. Beryllium decreases melting temperature and corrosion resistance (Lee et al., 1985) while improving castability and bonding. Lower melting temperatures also provide a smoother casting surface that requires less finishing. Boron decreases alloy melting temperature (Haudin and Perrin, 1981). Titanium and manganese increase corrosion resistance (Meyer, 1977) and serve as bonding agents (Espevik and Øilo, 1979). Iron increases strength (Meyer et al., 1979). Cobalt increases hardness. Copper increases corrosion resistance (Bui and Dabosi, 1981). Gallium improves castability (Kollmannsperger and Helfmeier, 1983). Yttrium aids in the adherence of oxide layers (Townsend and Hamilton, 1983). Molybdenum increases corrosion resistance (Lee et al., 1985). Tin increases strength and hardness (Ando and Nakayama, 1983).

\section{CLINICAL EFFECTS/RPD ALLOYS}

Sufficient clinical experience with RPD alloys would indicate that there are no harmful side-effects; no studies suggest otherwise.

\section{CLINICAL EFFECTS/PFM ALLOYS}

In 1980 , a comprehensive 10 -year clinical study was activated (VA Cooperative Studies \#147) to study alloys of "representative chemical compositions" that included Olympia (Au-Pd), W-1 (Pd-Ag), ticon (Ni-Cr-based with Be), MicroBond N/P2 (Ni-Cr-based with Ga), and Ceramalloy II (Ni-Cr). The study was conducted at six Veterans Affairs Medical Centers, with $20 \mathrm{clinical} / \mathrm{basic}$ researchers and more than 600 patients ( 2400 restoration units). A paired-comparison design was used. Preliminary (72-month) data (Morris et al., unpublished) suggest the following:

(1) Number of re-makes/castings per restoration: Olympia $(\mathrm{Oly})=1.1 ; \mathrm{W}-1=1.2 ;$ Ticon (Tic) $=1.2$; Ceramalloy II $($ CeramII $)=1.1 ;$ and Micro-Bond N/P2 $(\mathrm{MicN} / \mathrm{P} 2)=1.3$.

(2) Total cost per unit: $\mathrm{Oly}=\$ 54.91 ; \mathrm{W}-1=\$ 31.48$; and base metals $=\$ 20.58$ (avg.).

(3) Changes in overall quality: Oly $=-0.48 ; \mathrm{W}-1=-0.75$; Tic $=-0.41 ;$ CeramII $=-0.73 ;$ and $\mathrm{MicN} / \mathrm{Ps}=-0.66$ (change of -1.00 units, on a five-point scale where $5=$ best and 1 = worst; considered by the research group to be clinically significant).

(4) Deterioration of porcelain: Oly $=-0.16 ; \mathrm{W}-1=-0.41$; Tic $=-0.25 ; \mathrm{MicN} / \mathrm{Ps}=-0.31 ;$ and $\mathrm{CeramII}=-0.68$ (change of -1.00 units, on a five-point scale, was considered clinically significant).

(5) Change in metal surface: Oly $=-0.69 ; \mathrm{W}-1=-0.72$; Tic $=-0.32$; CeramII $=-0.27$; and $\mathrm{MicN} / \mathrm{Ps}=-0.49$ (change of -1.00 units, on a five-point scale, was considered clinically significant; such changes appear to be related to hardness).

(6) Percentage of removals/failures: $6 \%$ of all restorations cemented (all restorations removed were considered "failures").

(7) Removals/failures for each alloy: Oly $=4 \%$; W-1 $=$ $7 \% ; \mathrm{Tic}=8 \% ; \mathrm{MicN} / \mathrm{Ps}=5 \% ;$ and CeramII $=13 \%$.

(8) Causes for removals/failures: about $60 \%$ were related not to materials but to technical/fabrication errors.

(9) Plaque index: slightly lower for cast restorations than "unrestored" periodontal controls.

(10) Gingival index: slightly higher for "restored teeth" than unrestored periodontal controls.

(11) Pocket depth: slightly higher for restored teeth than unrestored periodontal controls.

(12) Loss of an attachment: slightly greater for restored teeth than unrestored periodontal controls.

(13) Number of patients sensitized to nickel: All patients were patch-tested for nickel, chromium, and cobalt sensitivity each year for five years. No patients were sensitized due to a base metal dental restoration. 


\section{FUTURE DIRECTIONS FOR RESEARCH}

A comprehensive, cost-effective, scientific clinical research center needs to be established to address the numerous questions that exist in the areas of restorative materials and dental implants. This center would involve the coordinated efforts of both basic and clinical investigators and would focus research on (1) improving the sensitivity of clinical research instrumentation and methodologies, (2) defining the long-term effects of "materials" on "favorable and unfavorable" clinical performance, (3) determining the properties that are needed for clinical success, and (4) identifying the "in vitro tests" that accurately predict clinical success. This research will increase the cost-effectiveness and productivity of new materials, and it would ensure the long-term safety of current and new restorative materials.

\section{REFERENCES}

American Dental Association Council on Dental Materials, Instruments, and Equipment (1984). Classification system for cast alloys. $J$ Am Dent Assoc 109:766, 838-850.

Ando N, Nakayama M (1983). Sag resistance of non-precious alloys for porcelain fusing (abstract). J Dent Res 62:683.

Asgar K, Allan FC (1968). Microstructure and physical properties for alloys for partial denture casting. $J$ Dent Res 47:180-197.

Asgar K, Peyton FA (1961). Effect of microstructure on the physical properties of Co-base alloys. J Dent Res 40:63-72.

Bui N, Dabosi F (1981). Comportement electrochimique en milieu salin de quelques alliages dentaires à base de nickel et de cobalt. In: Metallurgie dentaire. Paris: CIMD 80/Pcy ed., 334-348.

Eichner K (1983). Anwendung von metall-legierungen in der zahnheilkunde-ein Überblick. ZWR 92:28-36.

Espevik S, Øilo G (1979). Oxidation of noble metal alloys for porcelain veneer crowns (abstract). J Dent Res 58:265.

German RM (1979). Lattice strain model of ceramo-metal alloy hardening (abstract). J Dent Res 58:263.

Haudin JM, Perrin, MY (1981). Rôle des elements d'addition $(\mathrm{B}, \mathrm{Si}, \mathrm{Al}, \mathrm{Be}$ ) sur la structure des alliages nickel-chrome. In: Metallurgie dentaire. Paris: CIMD 80/Pyc ed., 50-60.

Kojima S (1980). Investigations of sag-resistance of precious alloys for porcelain firing. Part 2: Effect of $\mathrm{Fe}, \mathrm{In}, \mathrm{Sn}$ addition on the distortion at high temperature. JDAM 22:21-36.

Kollmannsperger P, Helfmeier H (1983). Zur analyse von edelmetall dentallegierungen. Dtsch Zahnärztl Z38:10401045.

Labarage JJ, Treheux D (1979). Hardening of gold-based dental casting alloys. Influence of minor additions and thermal aging. Gold Bull 12:46.

Lee J, Lucas L, O'Neal J, Lacefield W, Lemons J (1985). In vitro corrosion analyses of nickel-base alloys (abstract). $J$ Dent Res 64:317.

McLean JW (1983). The metal-ceramic restoration. Dent Clin North Am 27:747-761.

Meyer JM (1977). Corrosion resistance of nickel-chromium dental casting alloys. Corrosion Sci 17:971-982.

Meyer JM, Payan J, Nallay JN (1979). Evaluation of alternative alloys to precious ceramic alloys. I. Mechanical properties. J Oral Rehabil 6:291-309.

Miller AJ, Brunelle JA, Carlos JP, Brown LJ, Löe H (1987). Oral health of United States adults. The national survey of oral health in U.S. employed adults and seniors: 19851986. National findings. Bethesda(MD): National Institute of Dental Research, NIH publication no. 87-2868.

Moffa JP (1983). Alternative dental casting alloys. Dent Clin North Am 27:733-746.

Morris HF, participants of CSP \#147 (1986). Veterans Administration cooperative studies project no. 147. Part I: a multidisciplinary, multicenter experimental design for the evaluation of alternative metal-ceramic alloys. $J$ Prosthet Dent 56:402-405.

Phillips RW (1991). Skinner's science of dental materials. 9th ed. Philadelphia: Saunders.

Raub CJ, Ott D (1983). Gold casting alloys. The effect of zinc additions on their behavior. Gold Bull 16:46-51.

Tesk JA, Waterstrat RM (1985). Physical metallurgy of dental casting alloys. Co-Cr-Mo system; Ni-Cr system; ferritic and austenitic, titanium alloys. In: Encyclopedia of materials science and engineering. Elmsford (NY): Pergamon Press.

Townsend JD, Hamilton AI (1983). Biologic evaluation of a silver-copper-germanium dental casting alloy and a goldgermanium coating alloy. J Dent Res 62:899-903.

Tuccillo JJ (1977). Composition and functional characteristics of precious metal alloys for dental restoration. In: Valega TM, ed. Alternatives to gold alloys in dentistry. Proceedings of a conference held at the National Institutes of Health. Bethesda (MD): DHEW publication new. (NIH) 77-1229, 40-67.

Tuccillo JJ, Nielsen JP (1971). Observations of onset of sulfide tarnish on gold-based alloys. $J$ Prosthet Dent 25:629-637. 